\title{
Evidence for diffuse extension of the Pacific plate from Pukapuka ridges and cross-grain gravity lineations
}

\author{
David T. Sandwell, Edward L. Winterer, and Jacqueline Mammerickx \\ Scripps Institution of Oceanography, La Jolla, California
}

Robert A. Duncan

College of Oceanography, Oregon State University, Corvallis

\author{
Mary Ann Lynch, Daniel A. Levitt, and Catherine L. Johnson \\ Scripps Institution of Oceanography, La Jolla, California
}

\begin{abstract}
Satellite altimeter measurements of marine gravity reveal 100 to $200-\mathrm{km}$ wavelength lineations over a wide area of the Pacific plate oriented roughly in the direction of absolute plate motion. At least three mechanisms have been proposed for their origin: smallscale convective rolls aligned in the direction of absolute plate motion by shear in the asthenosphere; diffuse N-S extension of the lithosphere resulting in lineated zones of extension (boudins); and minihotspots that move slowly with respect to major hotspots and produce intermittent volcanism. Recently, several chains of linear volcanic ridges have been found to be associated with the gravity lineations. Following ridgelike gravity signatures apparent in highresolution Geosat gravity measurements, we surveyed a series of volcanic ridges that extend northwest from the East Pacific Rise flank for $2600 \mathrm{~km}$ onto 40 Ma seafloor. Our survey data, as well as radiometric dates on samples we collected from the ridges, provide tight constraints on their origin: (1) Individual ridge segments and sets of ridges are highly elongate in the direction of present absolute plate motion. (2) The ridges formed along a band 50 to $70-\mathrm{km}$-wide in the trough of one of the more prominent gravity lineations. (3) Radiometric dates of the largest ridges show no hotspot age progression. Moreover, the directions predicted for minihotspot traces older than $24 \mathrm{Ma}$ do not match observed directions of either the gravity lineations or the ridges. Based on this last observation, we reject the minihotspot model. The occurrence of the ridges in the trough of the gravity lineation is incompatible with the small-scale convection model which would predict increased volcanism above the convective upwelling. We favor the diffuse extension model because it is consistent with the occurrence of ridges in the trough above the more highly extended lithosphere. However, the multibeam data show no evidence for widespread normal faulting of the crust as predicted by the model. Perhaps the fault scarps are buried under more than $30 \mathrm{~m}$ of sediments and/or covered by the elongated ridges. Finally, we note that if ridge-push force is much smaller than trench-pull force, then near the ridge axis the direction of maximum tensile stress must be perpendicular to the direction of absolute plate motion.
\end{abstract}

\section{Introduction}

Perhaps the most important finding of the Seasat altimeter mission was the discovery in the marine gravity field of a lineated pattern that is associated with the young parts of fastmoving oceanic plates [Haxby and Weissel, 1986]. These gravity lineations are composed of linear troughs and swells having amplitudes of $5-20 \mathrm{mGal}$ and characteristic wavelengths of 100-200 $\mathrm{km}$. In the south central Pacific, they are oblique, cross-grain, to both fracture zones and abyssal hill fabric but are roughly parallel to the Hawaiian Chain (Plate 1). Cross-grain lineations are apparent on both young ( $\sim 5 \mathrm{Ma})$ and old ( $\sim 80 \mathrm{Ma})$ seafloor. While they do not extend

Copyright 1995 by the American Geophysical Union.

Paper number $95 \mathrm{JB} 00156$.

0148-0227/95/95JB-00156\$05.00 to the axis of the East Pacific Rise (EPR), they appear to develop rapidly on young seafloor $(\sim 3 \mathrm{Ma})$, and on lithosphere older than $6 \mathrm{Ma}$ they are well developed [Haxby and Weissel, 1986; Shen et al., 1993] (Plate 1). There is an indication that the wavelength of the cross-grain lineations increases to $300-1000 \mathrm{~km}$ on older seafloor, although gravity signatures from seamount chains and fracture zones may dominate the smaller amplitude cross-grain lineations [Haxby and Weissel, 1986; Baudry and Kroenke, 1991; Maia and Diament, 1991; Cazenave et al., 1992; Fleitout and Moriceau, 1992; Wessel et al., 1994].

More dense satellite-altimeter coverage, from Geosat and ERS 1, confirms the original observation of the cross-grain gravity lineations but also reveals narrow ridgelike anomalies which generally occur in the cross-grain gravity troughs (Plate 1). Winterer and Sandwell [1987] made a multibeam bathymetry survey in the equatorial Pacific (A - $\mathrm{A}^{\prime}$ in Plate 1$)$ 


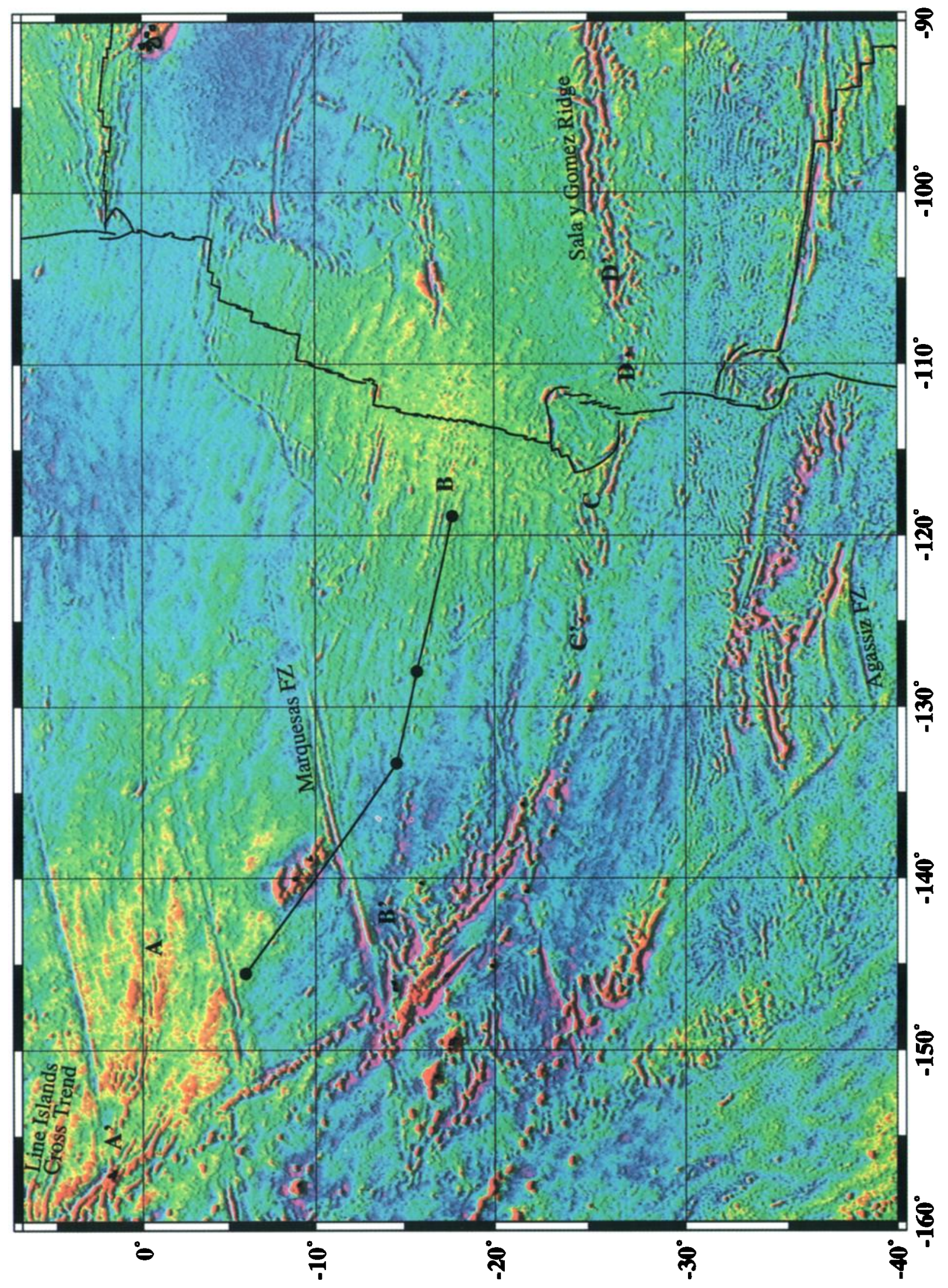


where they discovered a chain of long, linear volcanic ridges which appears to be an extension of the Line Island Cross Trend [Winterer, 1976]. Higher-resolution gravity fields that have become available since 1987 show that the western portion of this chain of ridges lies on the crest of a gravity lineation while the eastern portion lies in a trough. Searle et al. [1995] used a few GLORIA and multibeam swaths [Okal and Cazenave, 1985] to locate and survey a chain of linear volcanic ridges between Ducie Island and the Easter microplate (C - $\mathrm{C}^{\prime}$ in Plate 1); the ridges had characteristics similar to the cross-grain ridges [Winterer and Sandwell, 1987] as well to those ridges mapped north of Hawaii [Kayen et al., 1990]. Guided by similar high-resolution satellite altimeter profiles, we surveyed a chain of linear volcanic ridges along a 2600 $\mathrm{km}$-long corridor between Pukapuka Island in the Tuamotus and the western flank of the East Pacific Rise (B - B' in Plate 1, Pukapuka Ridges); our findings are presented in this paper. More recently, a similar set of ridges has been surveyed between Easter Island and Sala y Gomez Island on the eastern flank of the EPR [Naar et al., 1993] (D - D' in Plate 1).

The discovery of the linear volcanic ridges is important for at least two reasons: First, they represent a class of volcanic structure that is morphologically distinctly different from ordinary conical seamounts [Lynch, 1993]. Second, because the ridges are closely aligned with the cross-grain gravity lineations, they may have been produced by a common mechanism, and thus surveying and sampling the ridges can lead to better understanding of this common mechanism. The three mechanisms that have been proposed for the formation of the lineations are (1) small-scale convective rolls in the asthenosphere aligned in the direction of absolute plate motion by the shear of the Pacific plate [Haxby and Weissel, 1986; Buck and Parmentier, 1986]; (2) N-S extension of the Pacific plate resulting in lithospheric boudinage [Winterer and Sandwell, 1987; Dunbar and Sandwell, 1988; Fleitout et al., 1989]; and (3) minihotspots that move slowly with respect to major hotspots and produce intermittent volcanism [Fleitout and Moriceau, 1992].

Here we report results from our survey of the Pukapuka Ridges aboard R/V Melville in December 1992 and January 1993. Our multibeam depth soundings establish that the volcanic ridges are tightly aligned along the trough of one of the most continuous and prominent gravity rolls. We use the morphology of the ridges to infer the direction of tensile stress within the lithosphere at the time the ridges formed. Marine magnetic anomalies, collected during our cruises, as well as during many previous E-W cruises in the area, establish the crustal age pattern. Radiometric ages of rocks dredged from the most prominent ridges establish the timing and evolution of the ridges along the chain. We use all of this information to place constraints on the mechanism of formation of the cross-grain gravity lineations and associated volcanic ridges.

Plate 1. Gravity anomaly derived from ERS 1, Geosat, TOPEX, and Seasat altimeter profiles [Sandwell et al., 1994] illuminated from north. East Pacific Rise axis is marked by line. Solid circles connected by line are trace of fixed hotspot located at southeast end of chain $6.9 \mathrm{Ma}$; other solid circles are at 18, 24, and $43 \mathrm{Ma}$. A-A', B-B', C-C', and D-D' mark locations of volcanic ridges surveyed with multibeam systems. Note the higher-resolution data show a reduction in the wavelength of the gravity lineations toward the EPR from $150 \mathrm{~km}$ at $120^{\circ}-130^{\circ} \mathrm{W}$ to about $110 \mathrm{~km}$ at $115^{\circ} \mathrm{W}$.

\section{Data}

\section{Multibeam Bathymetry}

Prior to our survey, bathymetric coverage of the area was very sparse [Mammerickx and Smith, 1984; Mammerickx, 1992]; there were 11 single-beam sounding lines and 7 multibeam sounding lines across the $2600-\mathrm{km}$ length of the Pukapuka Ridges. Because the ridges are generally quite small, their gravity expressions are not apparent on individual Seasat altimeter profiles and become apparent only in stacked Geosat altimeter profiles [Sandwell and McAdoo, 1990]. We used these higher-resolution Geosat profiles along with previous soundings to guide a three-swath, Sea Beam 2000 bathymetric survey from 5 Ma seafloor near the East Pacific Rise to the northern edge of the Tuamotu Archipelago at Pukapuka Island (Figure 1, light gray lines). The Sea Beam 2090 has a swath width of 3.4 times the water depth :o three parallel swaths generally covered a zone $40 \mathrm{~km}$ wide. Six additional N-S transects were run across the most prominent ridges and out onto the crests of the adjacent cross-grain gravity highs; these provided long, straight gravity anomaly profiles perpendicular to the cross-grain gravity lineations and also provide estimates of volcano density away from the main line of the ridges. Our N-S multibeam swaths were augmented by six multibeam profiles collected in 1985 by R/V Conrad [Abers et al., 1988] and one multibeam profile collected by $\mathrm{R} / \mathrm{V}$ Washington in 1991. Two recent Sea Beam 2000 cruises also cross the ridges in roughly E-W directions (Westward Legs 1 and 4).

Contour maps (500-m interval) of the gridded bathymetry (Figures 2a-2d) show the overall locations and heights of the Pukapuka ridges; shading reveals smaller seamounts as well as the abyssal fabric. Volcanic ridges and seamounts are nearly continuous over the $2600-\mathrm{km}$-long, 50 to $75-\mathrm{km}$-wide chain. The major structures in the chain are composed of numerous ridge segments arranged both end-to-end and en echelon. En echelon ridges are commonly sigmoidal, and most are stacked dextrally at angles of $5^{\circ}-20^{\circ}$ to the overall Pukapuka trend. In areas where there are no prominent ridges, the seafloor spreading fabric is generally buried by small seamounts. The largest gap in volcanism $\left(-123.5^{\circ} \mathrm{W}\right)$ is about $130 \mathrm{~km}$ long, and there are a few other gaps $\left(100 \mathrm{~km}\right.$ at $128.5^{\circ} \mathrm{W}$ and $50 \mathrm{~km}$ at $139.8^{\circ} \mathrm{W}$ ). On all of the N-S transects, the abyssal hill fabric reemerges away from the main trend line of the ridges, suggesting that the volcanism occurs mainly in the trough of the cross-grain gravity lineation. Troughs in the gravity lineations are observed in areas where no large ridges are present so at least in these areas the gravity troughs are not due to the flexure of the lithosphere adjacent to ridges. Detailed flexure modeling of the ridges confirms that the gravity lineation is too broad and deep to be caused by ridge loading in areas where the ridges are tall (A. M. Goodwillie, Short-wavelength gravity lineations and unusual flexure results at the Pukapuka volcanic ridge system, manuscript in preparation, 1995).

Ridges are generally lower $(<1500 \mathrm{~m})$ and highly elongate along the eastern end of the chain and higher $(<4000 \mathrm{~m})$ and more conical along the western end. Detailed maps of three of the major ridge sets, having well-determined radiometric ages (see below), are shown in Figures 3a-3c. The easternmost set of six ridges forms a continuous structure $330 \mathrm{~km}$ long, $15 \mathrm{~km}$ wide, and $1000-1500 \mathrm{~m}$ high. About half of this structure is shown in Figure 3a; dredge sites with good recovery 2D, 3D, and $4 \mathrm{D}$ on the southern flank of the major volcano are marked. 


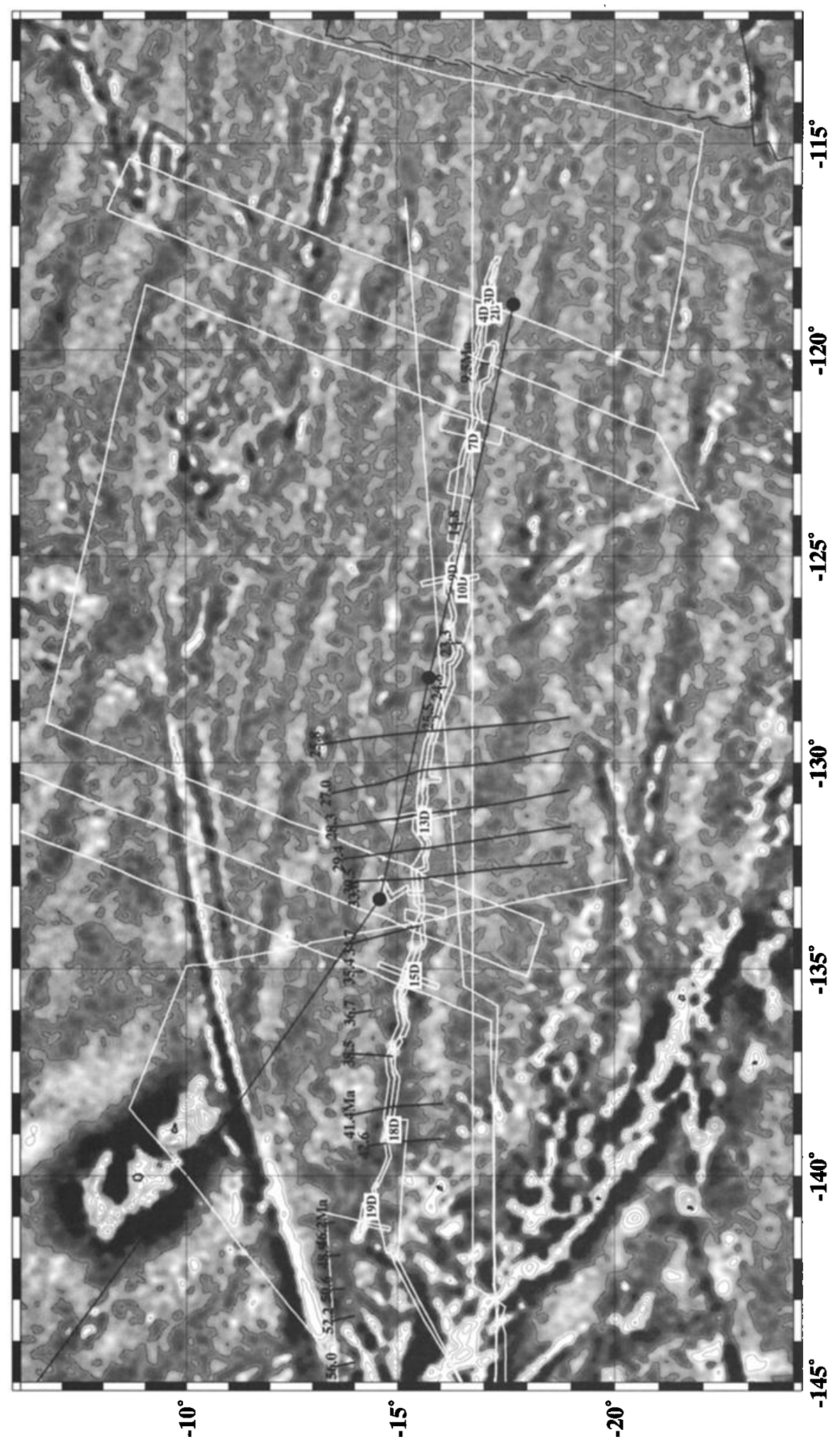

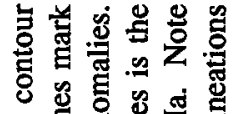

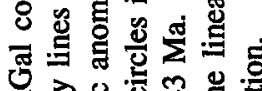

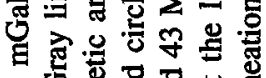

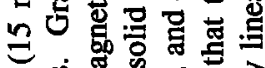

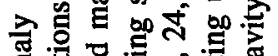

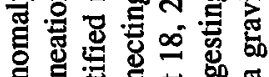

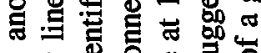

를워용

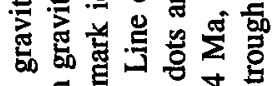

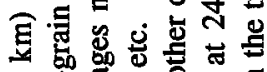

๙

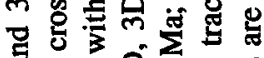

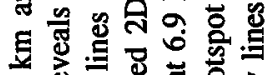

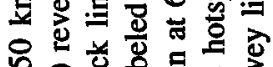

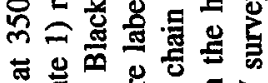

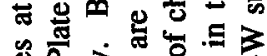

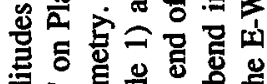

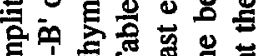

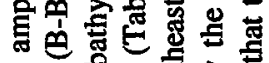

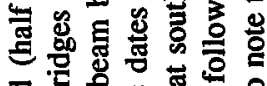

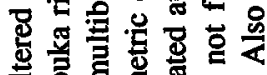

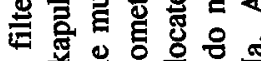

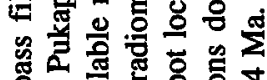

旁范密

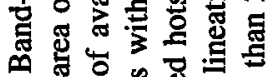

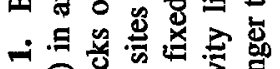

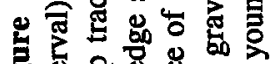

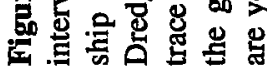



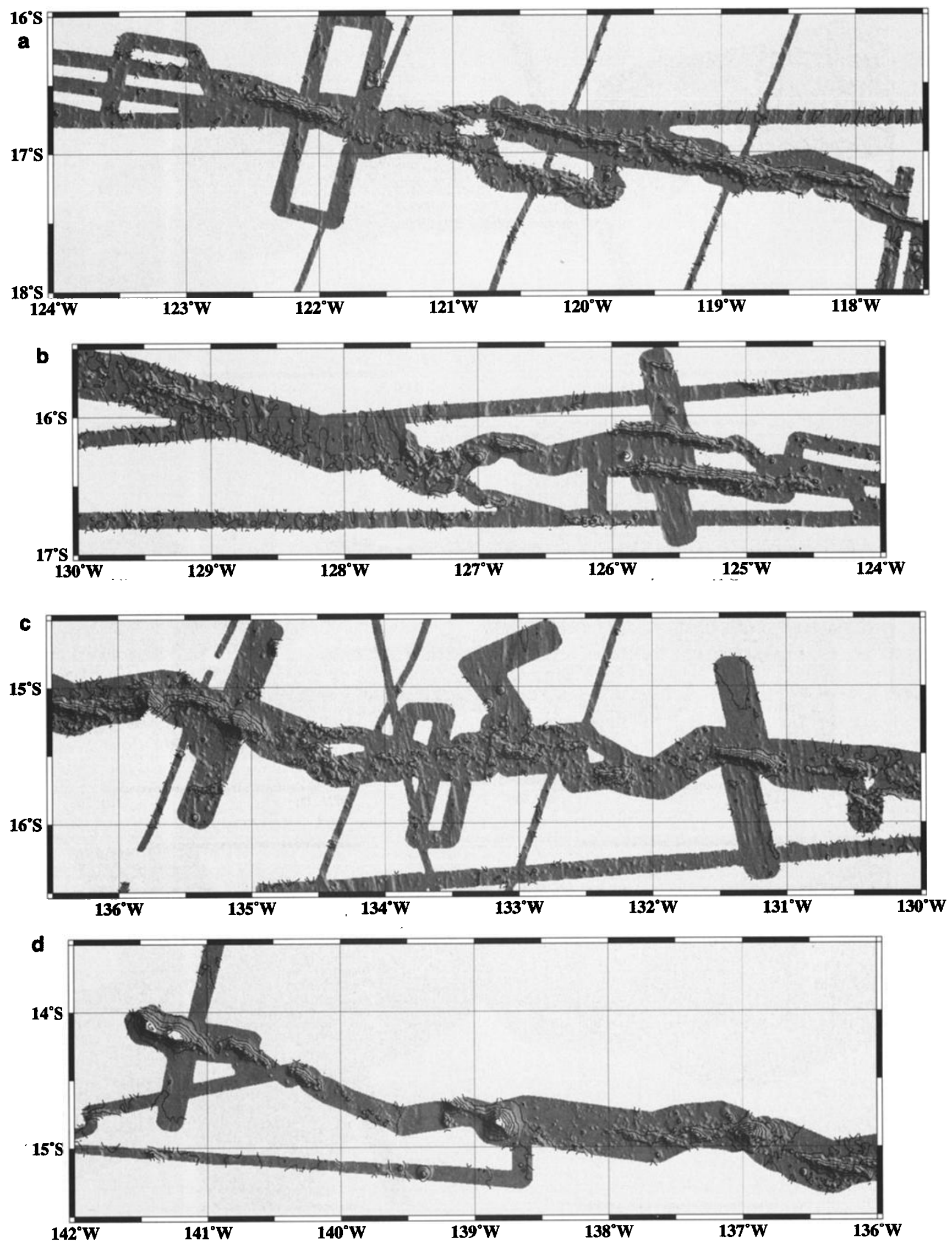

Figure 2. Bathymetry of Pukapuka ridges (500-m contour interval). Panels are arranged from (a) east to (d) west along the $2600-\mathrm{km}$-long chain. Illumination from ENE highlights abyssal hill fabric and smaller volcanoes. Largest gaps in volcanism are $125 \mathrm{~km}$ at $123.5^{\circ} \mathrm{W}, 100 \mathrm{~km}$ at $128.5^{\circ} \mathrm{W}$, and $50 \mathrm{~km}$ at $139.8^{\circ} \mathrm{W}$. 

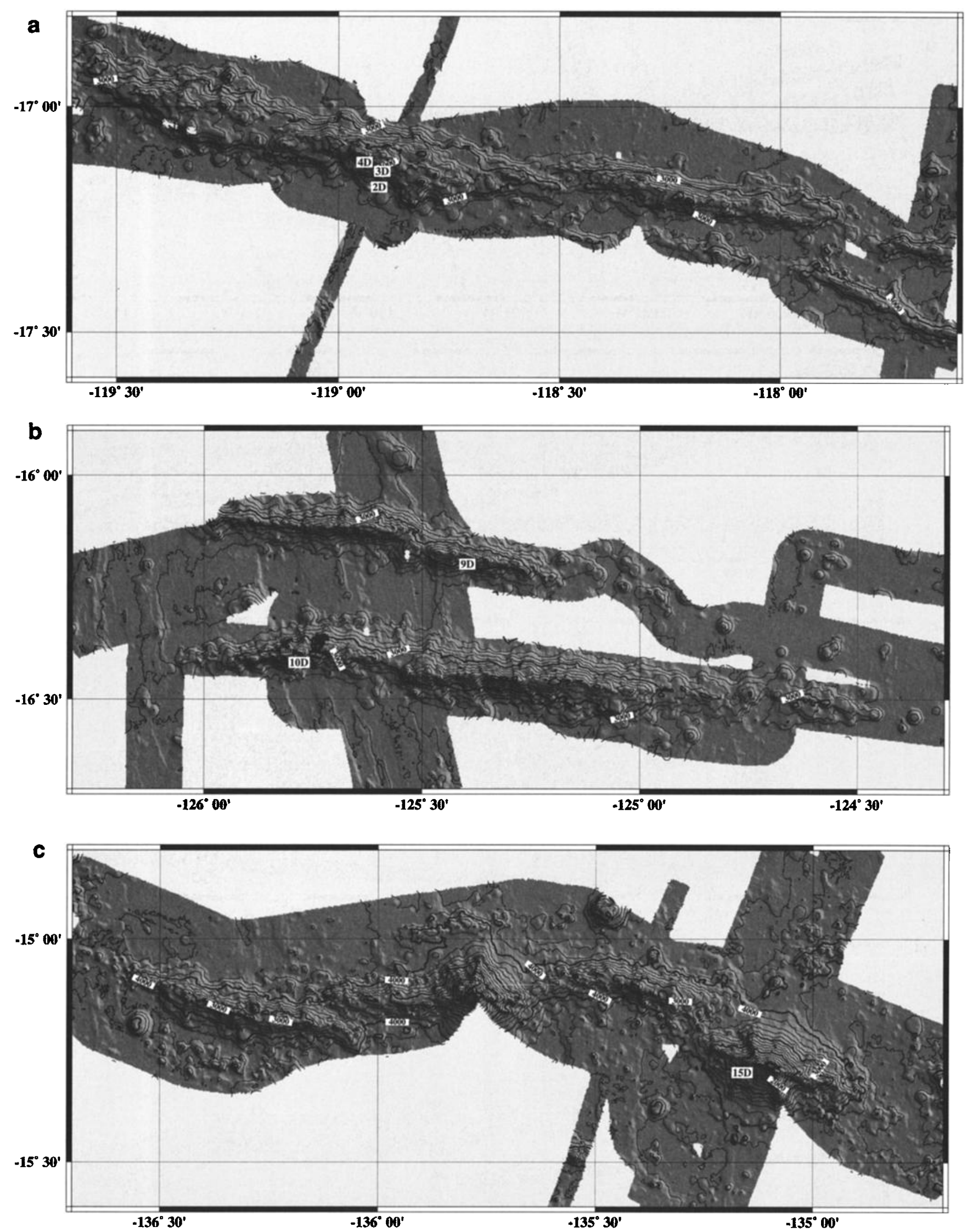

Figure 3. Detailed bathymetry of the longest $(330 \mathrm{~km}$ ) cluster of (a) ridges, (b) a pair of ridges, and (c) the highest ridge $(4000 \mathrm{~m}$ Wahoo Guyot). Major and minor contours intervals of $1000 \mathrm{~m}$ and $200 \mathrm{~m}$, respectively. Illumination from ENE highlights abyssal hill fabric and smaller volcanoes. Dredge sites are marked 2D, 3D, 4D, etc. 
This ridge, like most of the other ridges in the chain, is composed of individual segments that are typically about 35$50 \mathrm{~km}$ long and $15 \mathrm{~km}$ wide. An analysis of both the bathymetry and side scan data (not shown) suggests that ridges are built of several score individual volcanoes averaging about $400 \mathrm{~m}$ high and $3000 \mathrm{~m}$ wide, stacked in stepped tiers about $400 \mathrm{~m}$ high.

A pair of prominent ridges (80 and $120 \mathrm{~km}$ long) was surveyed about a third of the way along the Pukapuka chain (Figure $3 b$ ). Like the ridges farther to the east, this pair is composed of many $\sim 35-\mathrm{km}$-long segments where each segment consists of numerous stacked small volcanoes. These ridges are slightly narrower and sharper crested than the eastern ridge (Figure 3a). Abyssal hill fabric extends all the way to the base of the ridges as well as between the ridges. Samples of basalt, suitable for radiometric dating, were recovered on the southern flanks of the two major ridges (9D and 10D in Figure 3b).

The most prominent of the previously uncharted features in the Pukapuka chain is a 4000-m-high guyot (informally named Wahoo, from a variety of tuna in these waters) having a small flat summit at a depth of $380 \mathrm{~m}$. Wahoo Guyot, like many of the other ridges forming the western part of the chain, is higher and more conical than the eastern ridges. Based on a seafloor age of $35 \mathrm{Ma}$ (see next section) and a summit depth of $380 \mathrm{~m}$, one can predict the time the guyot was submerged

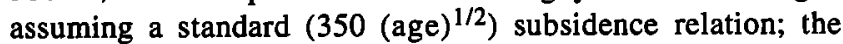
calculation yields $11.7 \mathrm{Ma}$. Dredge 14D brought back modern deep-water corals, while dredge 15D on the flank of the volcano yielded basalt radiometrically dated at $11.5 \mathrm{Ma}$. The small $(300 \times 600 \mathrm{~m})$, flat summit suggests that the seamount was above sea level for a short time, and thus a match of the subsidence age and the radiometric age is expected. This young age at the western end of the chain provides a strong constraint on the evolution of the chain.

\section{Crustal Ages}

The crustal age of the seafloor between the Marquesas and Austral fracture zones until now was poorly known. The three parallel E-W magnetic anomaly profiles, collected during our cruise, along with other E-W anomaly profiles in the area were used to establish a consistent set of anomaly identifications. In a few places the anomaly pattern was obscured when the ship passed directly over a major magnetized ridge but in most places, the original reversal signature was apparent on the other two adjacent tracks. A synthetic profile based on the timescale of Cande and Kent [1992] was calculated and compared with the observations to locate the leading edge of major reversals (Figure 1, black lines with ages in Ma). A complete set of magnetic anomalies is observed over $2000 \mathrm{~km}$ from the EPR to the $31 \mathrm{Ma}$ isochron. The many short-lived reversals around anomaly 5 and 6 times were difficult to identify, with the result that the age constraints are widely spaced at the eastern end of the chain. Between the ridge axis and $31 \mathrm{Ma}$, the average full spreading rate is $135 \mathrm{~mm} / \mathrm{yr}$ which is compatible with the very fast spreading rates observed presently at the EPR.

A possible rift initiation site, where crust was transferred to the Nazca plate, was surveyed at a longitude of $133^{\circ} \mathrm{W}$, and west of the $30.5 \mathrm{Ma}$ isochron. At this site the normal NNW trending seafloor spreading fabric is interrupted by a NNE trending trough/ridge structure (Figure $2 \mathrm{c}$ ). The 3-km-wide, flat-bottomed trough is bounded on the west by a 250 -m-high ridge; in addition there is a 100-m offset in the regional seafloor depth across this structure. Interpretation of the magnetic anomaly profiles to the west of this site reveals a gap in seafloor age of about $1.5 \mathrm{Ma}$ which is compatible with a regional depth offset. Farther to the west, the crustal age increases monotonically from $33 \mathrm{Ma}$ to about $61 \mathrm{Ma}$.

\section{Radiometric Dating of Ridge Samples}

Ten of the freshest dredged samples, from widely distributed sites along the chain, were selected for radiometric age determinations by the ${ }^{40} \mathrm{Ar}-{ }^{39} \mathrm{Ar}$ incremental heating method [Dalrymple et al., 1981]. Samples were either crushed to 0.5 to $1.0-\mathrm{mm}$ chips, or cut as minicores (35 mm diameter) from the freshest interior portions of dredged rocks, and ultrasonically washed in deionized water. Approximately $1 \mathrm{~g}$ splits (cores) of the prepared samples were sealed in evacuated quartz tubes and irradiated in the Oregon State University reactor, where they received a neutron dose of about $0.7 \times 10^{18}$ neutrons $/ \mathrm{cm}^{2}$. The neutron flux gradient and the efficiency of conversion of ${ }^{39} \mathrm{~K}$ to ${ }^{39} \mathrm{Ar}$ by neutron capture were monitored with samples of the biotite standard FCT-3 $(27.7 \pm 0.2 \mathrm{Ma}$ [Hurford and Hammerschmidt, 1985]). Further details of the experimental procedure, instrumentation, and data reduction are given by Duncan [1991].

Argon was extracted from samples in a series of five to seven heating steps, by radio frequency induction heating, and measured by mass spectrometry (instrument AEI MS-10S). Ages were calculated from the isotopic composition of $\mathrm{Ar}$ released in each step, and plateau ages (Table 1) are the weighted mean of concordant step ages. Isochron ages were determined from ${ }^{39} \mathrm{Ar} /{ }^{40} \mathrm{Ar}$ versus ${ }^{36} \mathrm{Ar} /{ }^{40} \mathrm{Ar}$ correlation plots, which allow independent assessment of the sample age and the initial ${ }^{40} \mathrm{Ar} /{ }^{36} \mathrm{Ar}$ composition of the sample [Dalrymple et al., 1981]. Only those steps that produced concordant ages in the plateau plots were used in the isochron. The goodness of fit parameter SUMS has a $\chi^{2}$ distribution with $(N-2)$ degrees of freedom [York, 1969], $N$ being the number of steps used in the isochron regression. Experiments that yield an acceptable SUMS ( 2 or less), a ${ }^{40} \mathrm{Ar} /{ }^{36} \mathrm{Ar}$ intercept near the atmospheric value (295.5), and concordant plateau and isochron ages, are likely to have determined reliable crystallization ages [Lanphere and Dalrymple, 1978]. Examples of plateau plots from sites 2D, 7D, and 15D are shown in Figure 4. The plateau plot from sample 7D is significantly worse that the others and yields an age greater than the age of the underlying seafloor, so we do not consider it further.

Multiple samples from the same volcanic ridge (2D, 3D, and 4D) or spatially closely related sites (9D, 10D) produced very similar ages (Table 1). This reproducibility, and the internal consistency of the results from the ${ }^{40} \mathrm{Ar}-{ }^{39} \mathrm{Ar}$ incremental heating experiments, lead us to conclude that all samples (except 7D) produced reliable estimates of the age of construction of the volcanic ridges along this chain. Ages of the ridges vary from about 6 to $13 \mathrm{Ma}$ between the eastern end of the chain (2D, 3D, 4D) and Wahoo Guyot (15D), while the seafloor age varies from 7.7 to 35.5 Ma between these points. Pukapuka Island (18D) and Napuka Island (19D) are significantly older than the other ridges at $22 \mathrm{Ma}$ and $28 \mathrm{Ma}$, respectively.

\section{Discussion and Conclusions}

'Using these radiometric dates, we reject the minihotspot model [Fleitout and Moriceau, 1992] for the origin of the 
Table 1. Radiometric Ages of Basalts From the Pukapuka Ridges

\begin{tabular}{|c|c|c|c|c|c|c|}
\hline \multirow[b]{2}{*}{ Sample } & \multicolumn{2}{|c|}{ Age Spectrum } & \multicolumn{4}{|c|}{ Isochron } \\
\hline & ${ }^{39} \mathrm{Ar}, \%$ & Age $\pm 1 \sigma, \mathrm{Ma}$ & Age $\pm 1 \sigma, \mathrm{Ma}$ & Intercept $\pm 1 \sigma$ & $\frac{\text { SUMS }}{(N-2)}$ & $N$ \\
\hline $\begin{array}{r}2 \mathrm{D} \\
3 \mathrm{D} \\
4 \mathrm{D} \\
7 \mathrm{D} \\
9 \mathrm{D} \\
10 \mathrm{D} \\
13 \mathrm{D} \\
15 \mathrm{D} \\
18 \mathrm{D} \\
19 \mathrm{D}\end{array}$ & $\begin{array}{r}100 \\
98 \\
100 \\
55 \\
100 \\
92 \\
93 \\
100 \\
91 \\
80\end{array}$ & $\begin{array}{r}7.1 \pm 0.4 \\
5.6 \pm 0.3 \\
7.4 \pm 0.7 \\
17.6 \pm 1.6 \\
9.0 \pm 0.5 \\
9.0 \pm 0.2 \\
12.9 \pm 0.3 \\
11.5 \pm 0.1 \\
21.9 \pm 0.2 \\
27.5 \pm 0.4\end{array}$ & $\begin{array}{r}7.0 \pm 0.5 \\
5.6 \pm 0.1 \\
9.3 \pm 0.9 \\
16.9 \pm 2.5 \\
8.5 \pm 0.7 \\
8.5 \pm 0.4 \\
12.8 \pm 1.4 \\
12.7 \pm 0.8 \\
22.0 \pm 0.3 \\
26.2 \pm 0.6\end{array}$ & $\begin{array}{l}295.4 \pm 2.5 \\
298.4 \pm 0.4 \\
283.3 \pm 17.9 \\
296.6 \pm 5.2 \\
300.7 \pm 7.0 \\
308.3 \pm 5.1 \\
300.2 \pm 21.8 \\
279.9 \pm 7.2 \\
302.0 \pm 21.0 \\
319.6 \pm 8.3\end{array}$ & $\begin{array}{l}0.66 \\
0.02 \\
0.30 \\
0.26 \\
0.51 \\
2.70 \\
6.16 \\
1.24 \\
1.15 \\
0.31\end{array}$ & $\begin{array}{l}5 \\
5 \\
4 \\
3 \\
4 \\
5 \\
5 \\
4 \\
4 \\
4\end{array}$ \\
\hline
\end{tabular}

Ages calculated using the decay constants, $\lambda_{\varepsilon}=0.581 \times 10^{-10} \mathrm{yr}^{-1}, \lambda_{\beta}=4.963 \times 10^{-10} \mathrm{yr}^{-1}$, and biotite monitor FCT-3 $(27.7 \pm 0.2 \mathrm{Ma})$.

Pukapuka ridges although the model may still be valid for other seamount chains. This model, which was proposed to explain the cross-grain gravity lineations, has numerous plumes that are long lived and fixed with respect to each other. It has been proposed that these shallow mantle upwellings may also be responsible for intermittent volcanism along the chains [Fleitout and Moriceau, 1992; Shen et al., 1993]. We tested this concept using the absolute plate motion poles of Fleitout and Moriceau [1992] which are similar to other published poles [e.g., Lonsdale, 1988]. The minihotspot was placed at the easternmost dredge sites (2D, 3D and 4D) at a time of $6.9 \mathrm{Ma}$, and a predicted trail was generated out to 43 Ma. The solid circles in Plate 1 and Figure 1 correspond to times of $6.9 \mathrm{Ma}, 18 \mathrm{Ma}, 24 \mathrm{Ma}$, and $43 \mathrm{Ma}$. The model predicts ages of volcanism that can be compared with radiometric dates (Table 2). At dredge site 9D the model overpredicts the age by $6.3 \mathrm{Ma}$ and at Wahoo Guyot (15D) it over predicts the age by $14.5 \mathrm{Ma}$; this corresponds to a distance of $1300 \mathrm{~km}$ from the center of the hotspot! Postulating two hotspots along the same chain does not fit the data either. For example, if a hotspot is placed at site 9D to match the radiometric age of $8.5 \mathrm{Ma}$, then it will predict the wrong age at Wahoo Guyot. It may be possible to match the observations using three hotspots along a single chain but they must be perfectly aligned so they reinforce each other in the absolute plate motion direction. In addition to the poor fit to the ages, the minihotspot model fails to match the directions of the Pukapuka ridges and gravity lineations, especially beyond the kink in the hotspot trace at $24 \mathrm{Ma}$. The kink in absolute plate motion around $24 \mathrm{Ma}$ is needed to simultaneously match the geometries and ages of the Louisville and Hawaiian Hotspot chains [Lonsdale, 1988; Fleitout and Moriceau, 1992]. North Pacific hotspot data (mainly Hawaiian/Emperor data) could be fit either with a 24 Ma kink [Epp, 1978] or without a 24 Ma kink [Duncan and Clague, 1985] because the kink required by the Louisville data is less noticeable when projected into the North Pacific.

The small-scale convection models can explain the gravity lineations on younger seafloor but fails to match a number of our observations. First the original model, where the gravity rolls are actively supported on both young and old seafloor [Haxby and Weissel, 1986], predicts convective upwellings under the highs of the gravity (and topography) lineations and downwellings under the troughs of the lineations (Figure 5). Volcanism is expected to occur above the upwellings where temperatures are higher. In contrast, the Pukapuka ridges and the associated volcanism are located in the trough; other uncharted linear volcanic ridges apparent in the satellitederived gravity are also preferentially in troughs of gravity lineations (Plate 1). Second, the small-scale convection model fails to explain the orientation and aspect ratio of long linear ridge since they predict small compressional stress in the troughs of the gravity rolls and small tensional stresses on the crests of the gravity rolls.

Finally, the more realistic small-scale convection model, proposed by Buck and Parmentier [1986], fails to match the observed orientations of the rolls on seafloor older than about $30 \mathrm{Ma}$. These model calculations, which included an elastic lithosphere, show that both the evolution of the convective planform and the increase in flexural wavelength with age will cause the wavelength of the gravity anomalies to increase dramatically after $10 \mathrm{Ma}$. For example, after $15 \mathrm{~m} . \mathrm{y}$. of cooling, the elastic lithosphere will attenuate the topographic relief associated with gravity rolls at $250-\mathrm{km}$ wavelength by $90 \%$; shorter-wavelength rolls are almost completely attenuated. The observed $200-\mathrm{km}$ wavelength of the gravity rolls on older lithosphere can only be explained by forming the rolls in the first $5 \mathrm{~m} . \mathrm{y}$. when the lithosphere is still flexible and freezing them into the growing lithosphere after about $10 \mathrm{~m} . y$. A fatal difficulty for the model is that according to the absolute plate motion model developed to explain the kink in the Louisville Ridge [Lonsdale, 1988, Figure 14], there was a change in absolute plate motion at about $24 \mathrm{Ma}$. Thus a kink in the gravity lineations should be apparent on seafloor older than 29-34 Ma yet no kink is apparent south of the Marquesas Fracture Zone (FZ) on seafloor older than 35 Ma.

The lithospheric-stretching model is most consistent with all of the observations. In this scenario, the most recent episode of stretching began about the time of the reorganization of Pacific-Nazca spreading at $24 \mathrm{Ma}$ and has continued until at least $6 \mathrm{Ma}$; most of the ridges formed between 13 and $6 \mathrm{Ma}$. As in the Basin and Range province of western North America, lithospheric boudins (150-200 km 


\section{Pukapuka Ridge basalt 2D-1}

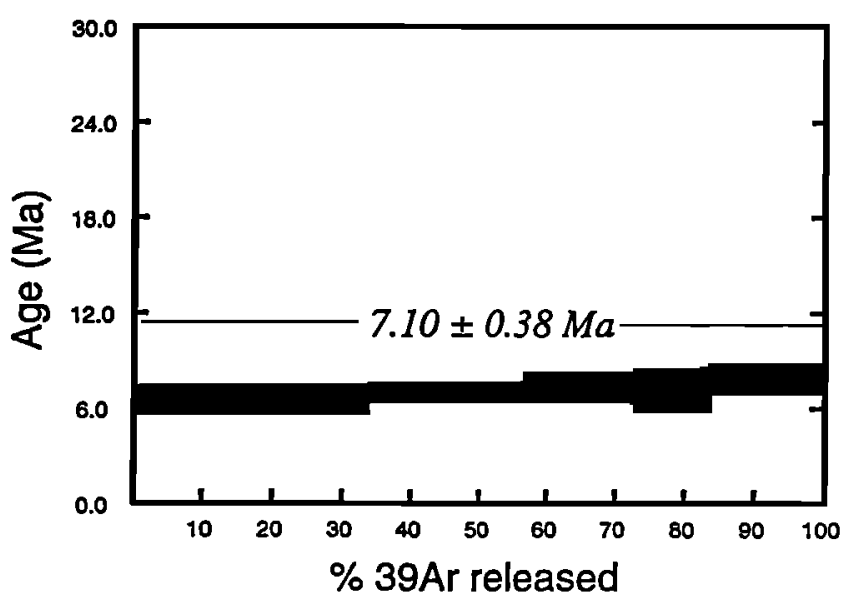

\section{Pukapuka Ridge basalt 7D-1}

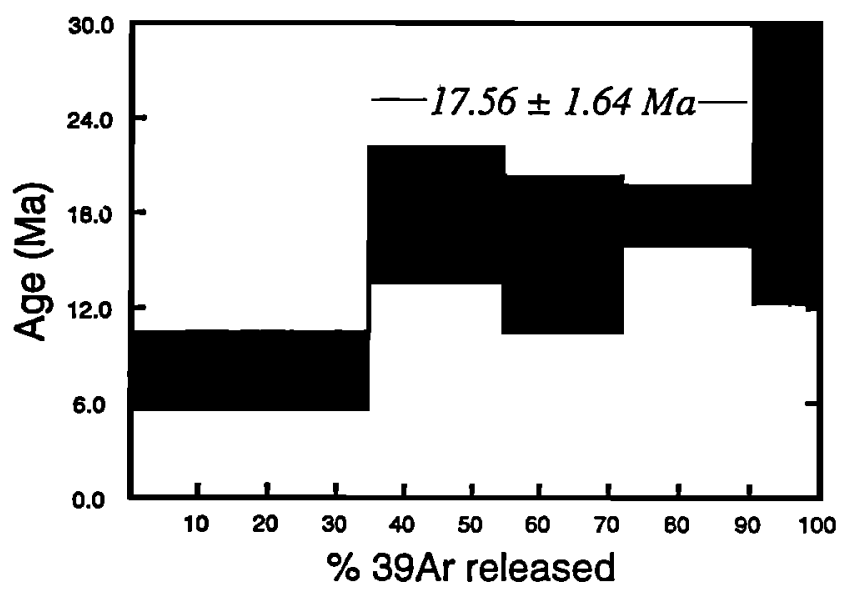

\section{Pukapuka Ridge basalt 15D-1}

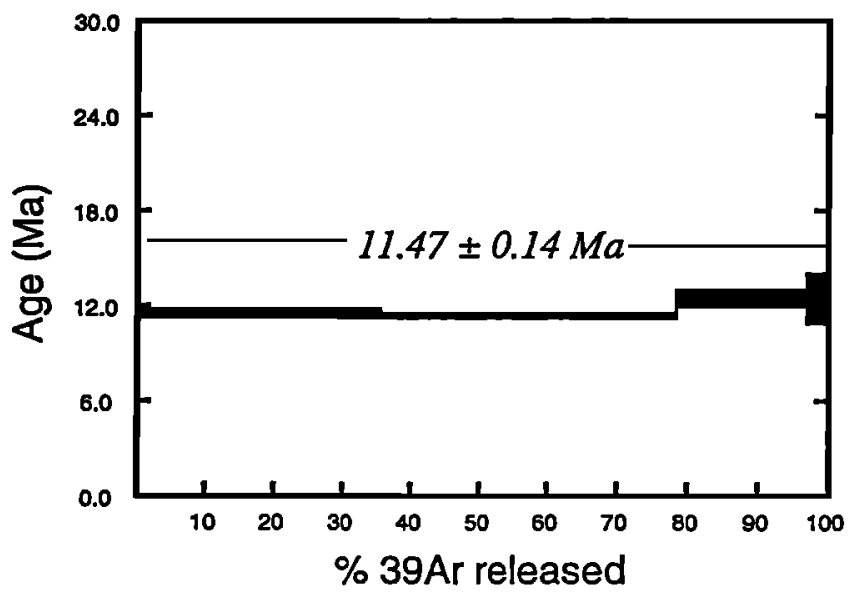

Figure 4. Plateau plots from ${ }^{40} \mathrm{Ar}-{ }^{39} \mathrm{Ar}$ incremental heating experiments for samples taken at dredge sites 2D, 7D, and 15D. Site $2 \mathrm{D}$ is at the eastern end of the chain on $7.7 \mathrm{~m} . \mathrm{y}$. seafloor, while site 15D is Wahoo Guyot, 35.5 m.y. seafloor. All plateau plots except 7D show consistent results with a low dispersion of ages. wavelength) develop in response to extension of a nonlinear strong layer above a weak asthenosphere [Fletcher and Hallet, 1983; Ricard and Froidevaux, 1986; Zuber et al., 1986]. At the proposed time of stretching (6-13 Ma), the oceanic lithosphere surrounding the Pukapuka ridges was 0-25 Ma old and thus thinner than the Basin and Range lithosphere so shorter wavelengths should be expected. Preliminary calculations [Dunbar and Sandwell, 1988] suggest that when zero-age brittle/ductile lithosphere is strained at a constant rate of $3 \times 10^{-16} \mathrm{~s}^{-1}$ as it cools and thickens with age, lithospheric boudins will develop after about $4 \mathrm{Ma}$ with a dominant wavelength of $145 \mathrm{~km}$. Most of the strain occurs in the topographic troughs, which also correspond to gravity troughs. This model explains the rapid development of gravity lineations on young seafloor, the approximate wavelength of the gravity lineations, the direction of gravity lineations on seafloor older than $24 \mathrm{Ma}$ and the direction of maximum tensile stress (see below). More recently, Neumann and Zuber [1994] have modeled the development of boudins in thickening oceanic lithosphere (3-13 Ma) undergoing $10 \%$ extension and found $50-\mathrm{km}$ wavelengths dominate in a brittle/plastic layer. Longer wavelengths (up to $200 \mathrm{~km}$ ) can occur in a brittle/ductile, but more strain is required.

The stretching model is also consistent with the elongation and orientation of the ridges if the ridges reflect linear cracks or faults in the upper brittle crust [Pollard et al., 1982]. Since the amount of stretching is too small to create significant decompression melting of the mantle, this model requires a reservoir of partial melt beneath the lithosphere; the melt escapes along cracks which are concentrated in the troughs of the boudins (Figure 5).

A potential problem with the stretching model is that significant extension has not been observed in plate reconstructions. The most prominent, young gravity lineations occur over a band of seafloor about $1500 \mathrm{~km}$ wide $\left(10^{\circ} \mathrm{S}\right.$ to $23^{\circ} \mathrm{S}$, Plate 1$)$. Assuming the most intense episode of stretching lasted for less than 20 m.y. (i.e., the age range of the ridges $26 \mathrm{Ma}$ until $6 \mathrm{Ma}$ ), the amount of extension should be less $20 \%(<300 \mathrm{~km})$ for a uniform strain rate of $3 \times 10^{-16}$ $\mathrm{s}^{-1}$. Of course, this strain rate is completely unknown, but other calculations [Neumann and Zuber, 1994] suggest more than $10 \%$ strain $(150 \mathrm{~km})$ is needed. By measuring distances between fracture zone pairs on either side of the EPR, Goodwillie and Parsons [1992] placed bounds on the amount of lithospheric extension; the maximum amount was found at $24 \mathrm{Ma}$ to be only 60 to $100 \mathrm{~km}$, which is far less than suggested by the preliminary models of $150-300 \mathrm{~km}$. Goodwillie and Parsons [1992] measured even less extension on older lithosphere. The simplest way to reconcile this observation with the boudinage model is to have nearly equal amounts of extension on both sides of the EPR. It has been proposed that extension is occurring on the east side of the EPR along the Sala y Gomez Ridge [Mammerickx and Sandwell, 1986]. Slab pull of the concave trench system along South America may be responsible for the tensional stress [Wortel and Cloetingh, 1981]. Rifting along the Sala y Gomez Ridge is also compatible with the morphology, continuity, and ages of the volcanoes of the $3000-\mathrm{km}$-long chain [Bonatti et al., 1977]. Six of seven volcanoes along this chain were active since $10 \mathrm{Ma}$, and there is no hotspot age progression along the chain [Bonatti et al., 1977].

A second potential problem with the stretching model is the lack of evidence for extensional faults parallel to the ridges. 
Table 2. Ages of Crust and Ridges

\begin{tabular}{ccccc}
\hline Dredge & Seafloor Age, Ma & Sample Age, Ma & Hotspot Age, Ma & $\begin{array}{c}\text { Sample Age - } \\
\text { Hotspot Age, Ma }\end{array}$ \\
\hline 2D & 7.7 & $7.1 \pm 0.4$ & 6.9 & 0.2 \\
3D & 7.7 & $5.6 \pm 0.3$ & 6.9 & -1.3 \\
4D & 7.7 & $7.4 \pm 0.7$ & 6.9 & 0.5 \\
7D & 12.0 & $17.6 \pm 1.6$ & 11.8 & 5.8 \\
9D & 18.5 & $9.0 \pm 0.5$ & 15.3 & -6.3 \\
10D & 19.5 & $9.0 \pm 0.2$ & 15.7 & -6.7 \\
13D & 28.5 & $12.9 \pm 0.3$ & 21.7 & -8.8 \\
15D & 35.5 & $11.5 \pm 0.1$ & 26.0 & -14.5 \\
18D & 42.3 & $21.9 \pm 0.2$ & 31.5 & -9.6 \\
19D & 45.4 & $27.5 \pm 0.4$ & 33.8 & -6.3 \\
\hline
\end{tabular}

The radiometric date of $7 \mathrm{D}$ exceeds the age of the seafloor, and in contrast to the other samples the plateau plot was inconsistent; incremental ages range from $7 \mathrm{Ma}$ to $20 \mathrm{Ma}$.

We have searched the multibeam and side scan images for evidence of tensional cracks but failed to find unequivocal examples. Except for the steep-sided Pukapuka ridges themselves, the seafloor in the survey area is covered in most places by a blanket of pelagic sediments. Although the reflections from the top of the oceanic crust beneath the sediment blanket are generally weak and intermittent, data from the $3.5-\mathrm{kHz}$ echo sounding along our survey tracks show that in the eastern part of the survey area, the sediments are generally about $40 \mathrm{~m}$ thick away from the ridges, and $60 \mathrm{~m}$ thick in the moatlike depressions flanking the ridges. Thicknesses increase steadily to about $100-200 \mathrm{~m}$ near the west end of the area. The boudinage model predicts widespread and pervasive extensional strain which is lowest on the crests of the boudins and greatest in the troughs of the boudins. The magnitude of the maximum strain is unknown but the preliminary models (described above) suggest $15-25 \%$. Since the extension is diffuse, the ridges cannot obscure all of the faults. The ability of observing the faults in multibeam data will depend on the height of the fault scarp relative to the thickness of sediments that have accumulated since the stretching event ended 6 to $16 \mathrm{Ma}$ ( 30 to $80 \mathrm{~m}$ based on an average $5 \mathrm{~m} / \mathrm{m} . \mathrm{y}$. accumulation rate). In addition, the vertical $(\sim 10 \mathrm{~m})$ and horizontal $(80 \mathrm{~m})$ resolution of the system will be a limiting factor. Lack of evidence for faulting suggests the faults are too small to be "seen" through the sediments (large $>100 \mathrm{~m}$ abyssal hill offsets are "seen"), or the surface expressions of the faults are too closely spaced to be resolved by the multibeam system, or the lithospheric stretching model is incorrect.

If the extension rate across the narrow Sala y Gomez Ridge matches the diffuse extension rate on the western flank of the EPR between the Garrett Transform and the Easter microplate, there will be shear at the EPR causing spreading direction to

\section{SMALL SCALE CONVECTION}

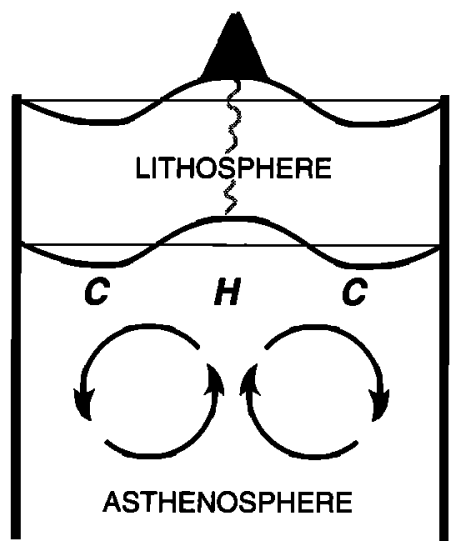

\section{EXTENSION}

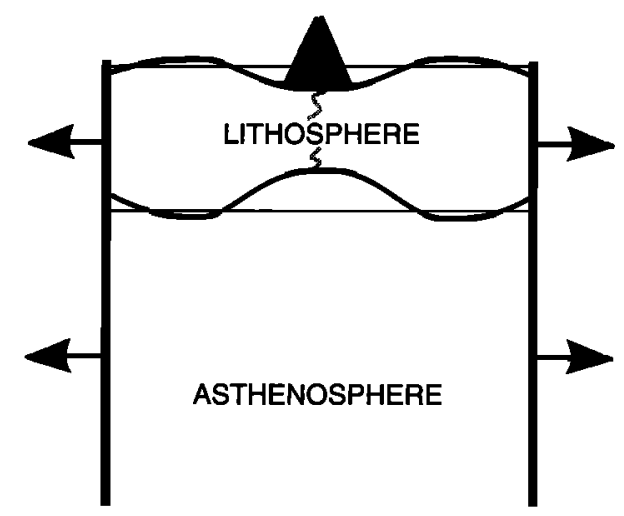

Figure 5. Conceptual models for cross-grain gravity lineations and volcanic ridges. (Left) Small-scale convection model predicts gravity and topography highs that reflect upwellings in the convection pattern. Hottest $(H)$ mantle temperatures and tensile stress occur beneath topographic highs while coldest $(C)$ temperatures and compressive stress occur in topographic lows. (Right) Extension model predicts topography lows and concentrations of tensile cracks in areas of highest extensional strain; magma leaks through thinner, fractured lithosphere. 
rotate in a clockwise sense by about $5^{\circ}$. Lonsdale [1989] has surveyed eight left-lateral nontransform offsets along this portion of the EPR and has attributed them to a recent clockwise change in spreading direction.

Finally, following Solomon and Sleep [1974] and Wortel and Cloetingh [1981], we propose that the source of extensional stress is the pull of subducting slabs at distant sites surrounding the Pacific and Nazca plates. The rapid absolute velocity of the Pacific plate causes the maximum tensile stress in the youngest part of the plate to be perpendicular to the direction of absolute plate motion. Figure 6 shows a schematic diagram of a fast-moving plate bounded on three sides by subduction zones and on the fourth side by a spreading ridge. We assume that the spreading ridge axis has no strength so it applies no force to the plate. The component of slab-pull force parallel to the absolute plate motion is exactly balanced by the integrated asthenospheric drag stress on the base of the plate. Moving toward the spreading ridge, this component of slab-pull force transmitted by the lithosphere must decrease to zero because the force at the ridge is zero. In contrast, the component of slab-pull force perpendicular to the absolute plate motion is transmitted

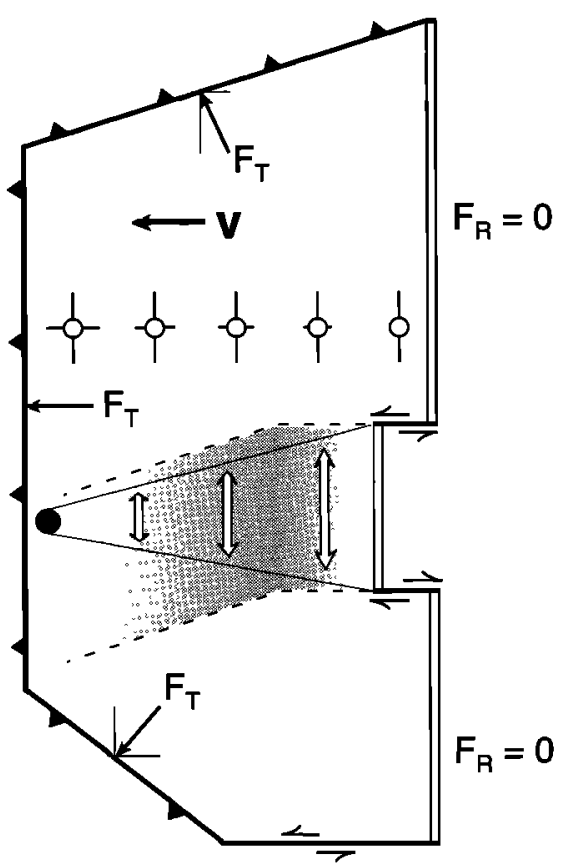

Figure 6. Schematic model of large oceanic plate surrounded by trenches on three sides and by a ridge on the fourth side. We assume that slab-pull force $F_{T}$ greatly exceeds ridge-push force $F_{R}$. The component of slab-pull force parallel to the absolute plate motion is balanced by the integrated asthenospheric drag stress on the base of the plate. This component of slab-pull force decreases to zero toward the spreading ridge (horizontal lines through circles). The component perpendicular to the absolute plate motion is transmitted across the plate from one trench to the other. Thus near the ridge axis the maximum tensile stress must be perpendicular to the direction of absolute plate motion. Yielding will occur preferentially in the youngest weakest lithosphere with a pole of opening near the western trench. Strain rate increases with distance from the pole. Grey level represents accumulated strain. across the plate from one trench to the other. Thus near the ridge axis the maximum tensile stress must be perpendicular to the direction of absolute plate motion. Larger, faster-moving plates will have more anisotropic stresses (and perhaps larger overall stress) than smaller, slower-moving plates because they have a larger drag force.

Now consider where yielding will occur. The overall lithospheric strength (i.e., yield strength integrated over depth) increases approximately linearly with age [Mammerickx and Sandwell, 1986]. Thus as the lithospheric end load is increased, the younger lithosphere yields before the older lithosphere. On the Pacific plate, the youngest and therefore the weakest segments of lithosphere occur south of the Marquesas FZ and north of the Agassiz FZ at $40^{\circ} \mathrm{S}$ (shown schematically by dashed lines in Figure 6). If force is applied evenly along the top and bottom boundaries of our schematic plate, then the plate will yield first near the spreading ridge between the fracture zones. Beyond the area between these fracture zones, the plates remain rigid, with the result that the relative motion between the northern and southern plates is described by a pole of opening. Since lithosphere is much stronger in compression than in extension and since our model contains no compressive driving forces, we speculate that the pole of opening will be located on the western side of the plate near the trench. Because extensional strain rate increases linearly with increasing distance from the pole, maximum strain rate occurs at the ridge axis; a small rate of compressional strain occurs on the western side of the pole. Based on these strength and geometry arguments, we speculate that the zone of extension is confined between the fracture zones and the amount of extension increases with increasing distance from the pole (Figure 6). If extension occurs over a period of time, strain will increase from zero at the ridge axis to a maximum on seafloor having the age corresponding to the beginning of extension. The model also predicts a slight difference in orientation of the northern EPR axis with respect to the southern EPR axis.

There are several ways this model can be tested: (1) Over the next 6 months, as the ERS 1 satellite altimeter continues to map the marine gravity field north of $30^{\circ} \mathrm{S}$, the increase in gravity resolution may clarify the relationship between the linear volcanic ridges and the gravity lineations. (2) Radiometric dating of samples recently collected along the Easter Volcanic Chain/Sala y Gomez Ridge (D. F. Naar, personal communication, 1993) and morphological analysis of the multibeam data may show whether there is evidence of rifting along this $3000-\mathrm{km}$ corridor. (3) Finally, because the boudinage model requires extension, although a variable amount, in the trough of each gravity lineation, the surface expression of this extension should either be a chain of volcanoes as in the Pukapuka area or normal faulting and cracking. Perhaps the fractures could be imaged with a highresolution subbottom profiling or imaging system.

There are several major implications of this lithospheric extension model. First, if there has been widespread extension of the large Pacific plate, then there are major uncertainties in plate-reconstruction models, which generally assume oceanic plates (except the Indian plate) behave rigidly. For example, several hundred kilometers of extension in the Pacific plate would cause an apparent motion between the Hawaiian and Louisville hotspots. Of course, with only two major hot spots to provide the absolute reference frame, extension can be recast as a perturbation to the absolute pole. 
Second, if one or more chains of linear volcanic ridges are shown to be formed by extension rather than by fixed hotspots as previously proposed, then the application of the fixed-hotspot model to other linear volcanic chains may be questioned. This is especially true of chains having no systematic radiometric age dates or chains having multiple linear age progressions. Finally, the alignment of maximum tensile stress perpendicular to the direction of absolute plate motion suggests that slab-pull force dominates ridge-push force and that slab pull is balanced by asthenospheric drag.

Acknowledgments. We thank the captain and crew of the R/V Melville for the flawless operation of the ship and facilities. We also thank Lew Hogan for laboratory assistance with the radiometric age determinations. Don Forsyth and Dan Scheirer helped to collect the initial pass of data along the Pukapuka ridges during Gloria Leg 3 . Thanks to the efforts of Stu Smith, Earl Heckman, and George Bouchard, the multibeam, gravity, and magnetics data flowed smoothly into the computers with no significant down time. Basalt samples were obtained at all of the important dredge sites thanks to the persistence of Ron Comer. Multibeam data were preprocessed and displayed using MB System [Caress and Chayes, 1993] and GMT System [Wessel and Smith, 1991] software, respectively. Tetsuro Urabe kindly let us use multibeam data collected during Westward Leg 1 . This research was supported by the National Science Foundation, Marine Geology and Geophysics Program (OCE90-19712).

\section{References}

Abers, G. A., B. Parsons, and J. K. Weissel, Seamount abundances and distributions in the southeast Pacific, Earth Planet. Sci. Lett., 87, 137151, 1988.

Baudry, M. and L. Kroenke, Intermediate-wavelength $(400-600 \mathrm{~cm})$, south Pacific geoidal undulations: Their relationship to linear volcanic chains, Earth Planet. Sci. Lett., 102, 430-443, 1991.

Bonatti, E., C. G. A. Harrison, D. E. Fisher, J. Honnorez, J.-G. Schilling, J. J. Stipp, and M. Zentilli, Easter volcanic chain (southeast Pacific): A mantle hot line, J. Geophys. Res., 82, 2457-2478, 1977.

Buck, W. R., and E. M. Parmentier, Convection beneath young oceanic lithosphere: Implications for thermal structure and gravity, $J$. Geophys. Res., 91, 1961-1974, 1986.

Cande, S. C., and D. V. Kent, A new geomagnetic polarity time scale for the late Cretaceous and Cenozoic, J. Geophys. Res., 97, 13917 $13951,1992$.

Caress, D. W. and D. N. Chayes, Status of Hydrosweep data processing and display on the R/V Maurice Ewing, M B System Manual, Lamont-Doherty Earth Obs., Palisades, N.Y., July 12, 1993.

Cazenave, A., S. Houry, B. Lago, and K. Dominh, Geosat-derived geoid anomalies at medium wavelength, $J$. Geophys. Res., 97, 7081-7096, 1992.

Dalrymple, G. B., E. C. Alexander, M. A. Lanphere, and G. P. Kraker, Irradiation of samples for ${ }^{40} \mathrm{Ar} /{ }^{39} \mathrm{Ar}$ dating using the Geological Survey TRIGA reactor, U.S. Geol. Surv. Prof. Pap., 1176, 55 pp., 1981.

Dunbar, J., and D. T. Sandwell, A boudinage model for crossgrain lineations (abstract), Eos Trans. AGU, 69, 1429, 1988.

Duncan, R. A., Age distribution of volcanism along the aseismic ridges in the eastern Indian Ocean, Proc. Ocean Drill. Program Sci. Results, 121, 507-517, 1991.

Duncan, R. A., and D. A. Clague, Pacific plate motion recorded by linear volcanic chains, in The Ocean Basins and Margins, edited by F. G. Stehli, A. E. M. Nairin and S. Uyeda, pp. 89-121, Plenum, New York, 1985.

Epp, D., Age and tectonic relationships among volcanic chains on the Pacific plate, Ph. D. thesis, Univ. of Hawaii at Manoa, 1978.

Fleitout, L., and C. Moriceau, Short-wavelength geoid, bathymetry and the convective pattern beneath the Pacific Ocean, Geophys. J. Int., $110,6-29,1992$.
Fleitout, L., C. Dalloubeix, and C. Moriceau, Small-wavelength geoid and topography anomalies in the South Atlantic Ocean - A clue to new hot-spot tracks and lithospheric deformation, Geophys. Res. Lett., 16, 637-640, 1989.

Fletcher, R. C., and B. Hallet, Unstable extension of the lithosphere: A mechanical model for Basin and Range structure, J. Geophys. Res., 88, 7457-7466, 1983.

Goodwillie, A. M., and B. Parsons, Placing bounds on lithospheric deformation in the central Pacific Ocean, Earth Planet. Sci. Lett., 111, 123-139, 1992.

Haxby, W. F., and J. K. Weissel, Evidence for small-scale mantle convection from Seasat altimeter data, J. Geophys. Res., 91, 3507$3520,1986$.

Hurfurd, A. J., and K. Hammerschmidt, ${ }^{40} \mathrm{Ar} /{ }^{39} \mathrm{Ar}$ and $\mathrm{K}-\mathrm{Ar}$ dating of the Bishop and Fish Canyon Tuffs: Calibration ages for fission-track dating standards, Chem. Geol., 58, 23-32, 1985.

Kayen, R. E., et al., Gloria sidescan sonar imagery of the Hawaiian Islands Exclusive Eccromiz Zone, Eos Trans. AGU, 71, 1580, 1990.

Lanphere, M. A., and G. B. Dalrymple, The use of ${ }^{40} \mathrm{Ar} /{ }^{39} \mathrm{Ar}$ data in evaluation of disturbed K-Ar systems, in Short Papers of the Fourth International Conference on Geochronology, Cosmochronology, and Isotope Geology, edited by R. E. Zartman, U.S. Geol. Surv. Open File Rep., 241-243, 1978.

Lonsdale, P., Geography and history of the Louisville hotspot chain in the southwest Pacific, J. Geophys. Res., 93, 3078-3104, 1988.

Lonsdale, P., Segmentation of the Pacific-Nazca spreading center, $1 \mathrm{~N}$ 20S, J. Geophys. Res., 94, 12197-12225, 1989.

Lynch, M. A., The crossgrain ridges: Linear ridge groups: Evidence for intraplate tension, Ph. D. thesis, Scripps Inst. of Oceanogr., La Jolla, Calif., 1993.

Maia, M., and M. Diament, An analysis of the altimetric geoid in various wavebands in the Pacific ocean, constraints on the origin of intraplate features, Tectonophysics, 190, 133-153, 1991.

Marnmerickx, J., Tectonic framework of the southcentral Pacific, Eos Trans. AGU, 73 (43), Fall Meeting Suppl., 587, 1992.

Mammerickx, J., and D. T. Sandwell, Rifting of old oceanic lithosphere, J. Geophys. Res., 91, 1975-1988, 1986.

Mammerickx, J., and S. M. Smith, General bathymetric chart of the oceans (GEBCO), 5th ed., Hydrographic Chart Distribution Office, Ottawa, Canada, 1984.

Naar, D.F., et al., GLORI-B and geochemical investigations of the Easter Seamount chain: EPR to San Ambrosio Island, Eos Trans. AGU, 74 (43), Fall Meeting Suppl., 672, 1993.

Neumann, G. A., and M. T. Zuber, Modeling constraints on diffuse extension on the Pacific Plate, Eos Trans. AGU, 75 (44), Fall Meet. Suppl., 590, 1994.

Okal, E., and A. Cazenade, Earth Planet. Sci. Lett., 72, 99-116, 1985.

Pollard, D. D., P. Segal, and P. T. Delaney, Formation and interpretation of dilatant echelon cracks, Geol. Soc. Am. Bull., 93, 1291-1303, 1982.

Ricard, Y., and C. Froidevaux, Stretching instabilities and lithospheric boudinage, J. Geophys. Res., 91, 8314-8324, 1986.

Sandwell, D. T., and D. C. McAdoo, High-accuracy, high-resolution gravity profiles from 2 years of the Geosat exact repeat mission, $J$. Geophys. Res., 95, 3049-3060, 1990.

Sandwell, D. T., M. M. Yale, and W. H. F. Smith, ERS-1 geodetic mission reveals detailed tectonic structures, Eos Trans. AGU, 75 (44), Fall Meeting Suppl., 155, 1994.

Searle, R. C., J. Francheteau, and B. Cornaglia, New observations on mid-plate volcanism and the tectonic history of the Pacific plate, Tahiti to Easter Microplate, Earth Planet. Sci. Lett., in press, 1995.

Shen, Y., D. W. Forsyth, D. S. Scheirer, and K. Macdonald, Two forms of volcanism: Implications for mantle flow and off-axis crustal production on the west flank of the southern East Pacific Rise, $J$. Geophys. Res., 98, 17875-17899, 1993.

Solomon, S. C., and N. H. Sleep, Some simple physical models for absolute plate motion, J. Geophys. Res., 79, 2557-2567, 1974.

Wessel, P. and W. H. F. Smith, Free software helps map and display data, Eos Trans. AGU, 72 (41), 441, 445-446, 1991. 
Wessel, P., D. Bercovici, and L. W. Kroenke, The possible reflection of mantle discontinuities in the Pacific geoid and bathymetry, Geophys. Res. Lett., 21, 1943-1946, 1994.

Winterer, E. L., Bathymetry and regional tectonic setting of the Line Island Chain, Initial Rep. Deep Sea Drill. Proj., 33, 731-747, 1976.

Winterer, E. L., and D. T. Sandwell, Evidence from en-echelon crossgrain ridges for tensional cracks in the Pacific plate, Nature, 329, 534-537, 1987.

Wortel, R., and S. Cloetingh, On the origin of the Cocos-Nazca spreading center, Geology, 9, 425-430, 1981.

York, D., Least-squares fitting of a straight line with correlated errors, Earth Planet. Sci. Lett., 5, 320-324, 1969.
Zuber, M. T., E. M. Parmentier, and R. C. Fletcher, Extension of continental lithosphere: A model for two scales of Basin and Range deformation, J. Geophys. Res., 91, 4826-4838, 1986.

R. A. Duncan, College of Oceanography, Oregon State University, Corvallis, OR 97331.

C. L. Johnson, D. A. Levitt, M. A. Lynch, J. Mammerickx, D. T. Sandwell, and E. L. Winterer, Scripps Institution of Oceanography, University of Califomia, San Diego, La Jolla, CA 92093-0225. (e-mail: sandwell@ radar.ucsd.edu)

(Received May 10, 1994; revised December 31, 1994; accepted January 12, 1995.) 